\title{
INCIDENCE OF PASTEURELLA SPECIES FROM NEWLY BORN PNEUMONIC CALVES IN KAFR EL-SHEIKH GOVERNORATE
}

\author{
Gamal El-Din Ibrahim Mazyed ${ }^{1}$, Hassan Hassan Kassem ${ }^{1}$, \\ Amgad Ahmed Moawad ${ }^{2}$, Ibrahim El-Sayed El-Desouky ${ }^{2}$ \\ ${ }^{1}$ Animal Health Research Institute, Kafrelsheikh, Provisional Lab., Agriculture \\ Research Center, Ministry of Agriculture, Egypt \\ ${ }^{2}$ Faculty of Veterinary Medicine, Kafrelsheikh University, Egypt
}

\begin{abstract}
Samples were collected from pneumonic calves from both sex under one month in Kafrelsheikh Governorate (150 nasal swabs from living calves and 20 pneumonic calves lung tissues recently dead calves). Samples were examined for the presence of Mannheimia multocida and $M$. haemolytica. Isolation, biochemical and serologic al identification revealed that a total of 124 non-repeated bacterial isolates were recovered from 170 pneumonic calves samples. Isolation revealed that a total of 47 (37.9\%) P. multocida and 38 (30.6\%) of $M$. haemolytica isolates were recovered.
\end{abstract}

\section{INTRODUCTION}

Bovine respiratory disease (BRD) remains the most common cause of morbidity and mortality in feed lot cattle (USDA, 2013), resulting in significant economic losses due to mortalities, treatment costs as reduced feed efficiency and animal product quality (Duff and Galyean, 2007). 
The most common bacteria found in the lung of calves with BRD include Mannheimia haemolytica and M. multocida (Pandher et al., 1998; Duff and Galyean, 2007; Griffin et al., 2010).

Today, we recognize that, $M$. haemolytica and $M$. multocida are associated with severe bacterial pneumonia frequently seen in dairy calves (Enzootic Pneum) and in feed lot cattle (shipping fever). Each has its own cadre of known virulence factors such as adhesions, toxins and enzymes that enhance its ability to colonize cause tissue destruction and incite an intense inflammatory response. It is generally believed that suppression of the host's immune system due to stress factor or viral infection predisposes to rapid growth of these bacteria in the upper respiratory tract reduced clearance in the lower respiratory system, initiating pathogenesis (Griffin et al., 2010).

Predisposing causes are generally synergistic and include, age, stress (commingling, weather, nutritional changes) and immunological background. Environmental risk factors include climate, ambient temperature, dust particles, stocking (Snowder et al., 2006).

The aim of this work was the incidence of Mannheimia species isolated from newly born pneumonic calves.

\section{MATERIALS AND METHODS}

\section{Sampling:}

A total of 170 samples (20 pneumonic lung tissues from recently dead calves and 150 nasal swabs from living calves) were collected randomly from sporadic calves both sex under one month old. 
Samples were collected within 4 months from December 2014 to March 2015 in Kafrelsheikh governorate. All samples were aseptically collected and sent to the laboratory.

Samples were incubated into brain heart infusion broth after an aerobic incubation at $37^{\circ} \mathrm{C}$, for $24 \mathrm{hrs}$, a loopful from the cultivated broth was streaked on the surface of OX blood agar, tryptose agar and Mackonkey's agar plate media. The incubated plates were incubated aerobically at $37^{\circ} \mathrm{C}$ for 24 hrs. Suspected colonies were picked up and subcultured into $7.5 \%$ oxblood agar for purification on moderate size, round and grayish, viscous mucoid colonies, neither haemolytic on blood agar nor growth on Mac Conkey agar (Mannheimia multocida) and one 1-2 $\mathrm{mm}$ in diameter grayish smooth colonies with a characteristic $\beta$ haemolysis on blood agar and growth on MacConkey's agar ( $M$. haemolytica).

\section{RESULTS}

Respiratory tract infections are of a common occurrence in various species of domestic and farm animals. However, pneumonic pasteurellosis, also known as respiratory mannheimiosis, is the most common example with a wide prevalence in ruminant animals. The disease, in its typical clinical form, is highly infectious, often fatal and with very serious economic impact in animal industry. It is well established that pneumonic pasteurellosis is responsible for the largest cause of mortality in feedlot animals in which the disease accounts for approximately $30 \%$ of the total cattle deaths worldwide. (Boudreaux, 2004). 


\subsection{Incidence of Mannheimia multocida and Mannheimia (Mannheimia haemolytica) isolated from pneumonic calf}

As shown figure (1) a total of 124 non repeated bacterial isolates were recovered from 170 pneumonic calf samples. Isolation and biochemical identification revealed that a total of 47 (37.9\%) Mannheimia multocida and 38 (30.6\%) Mannheimia haemolytica isolates were recovered.

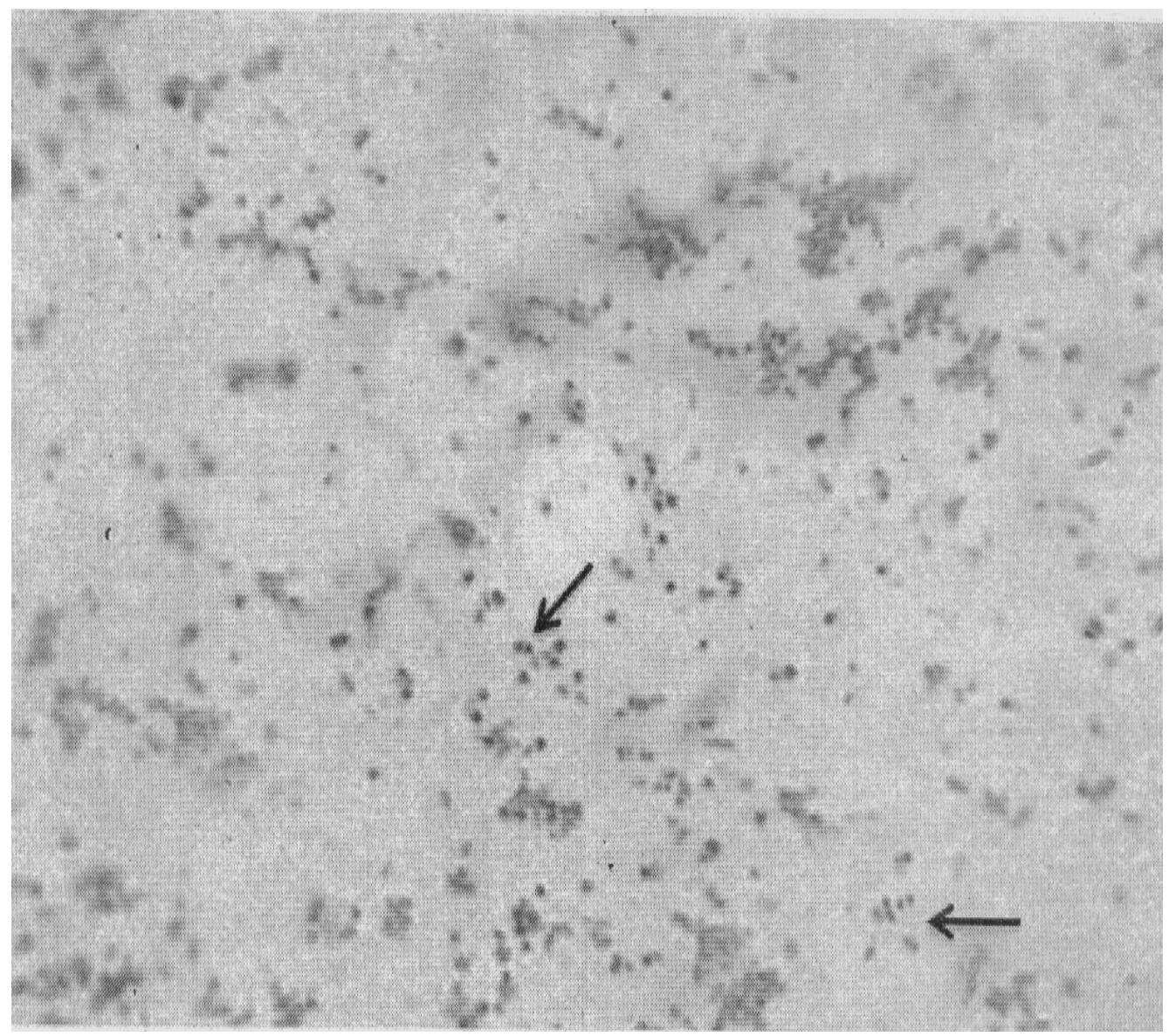

Photograph (1): Showing Mannheimia spp. in Gram stain Gram negative coccobacilli with the characteristic bipolar phenomena (arrow) 


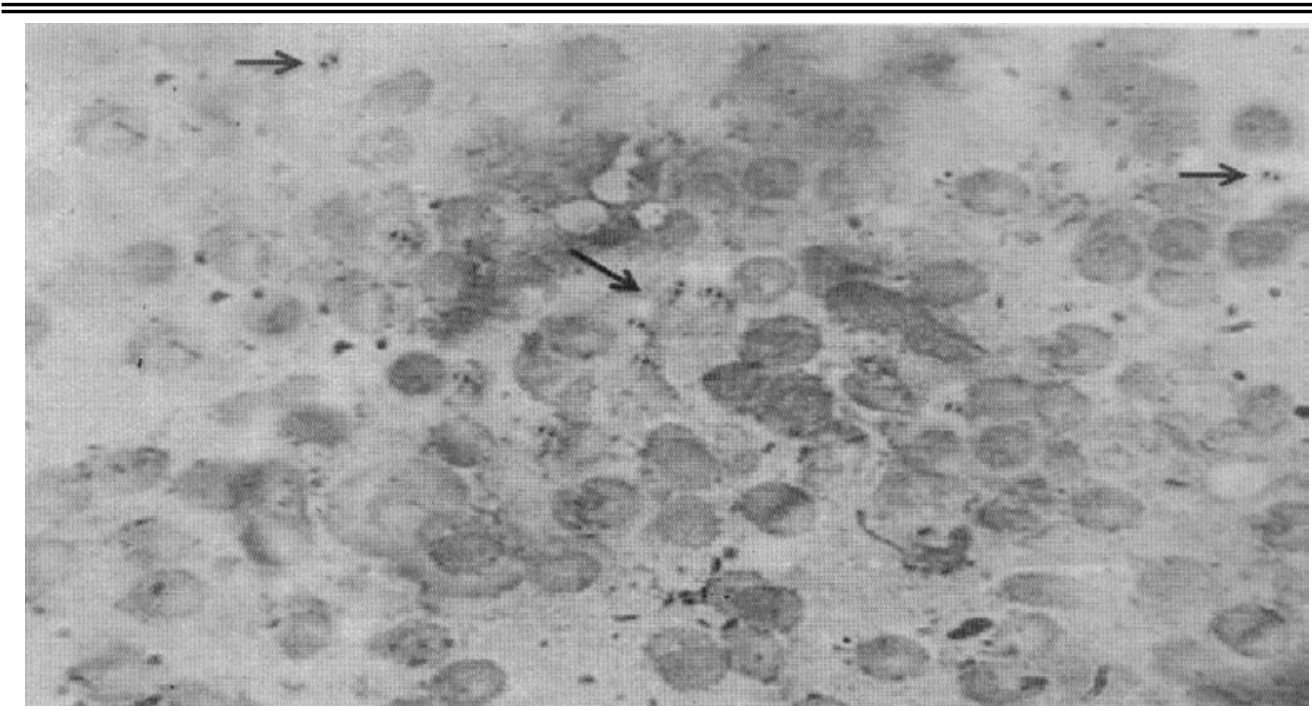

Photograph (2): Showing Mannheimia spp. in rat blood smear from a case of Septicaemia with the characteristic bipolar staining (Giemsa Stain,X1000)

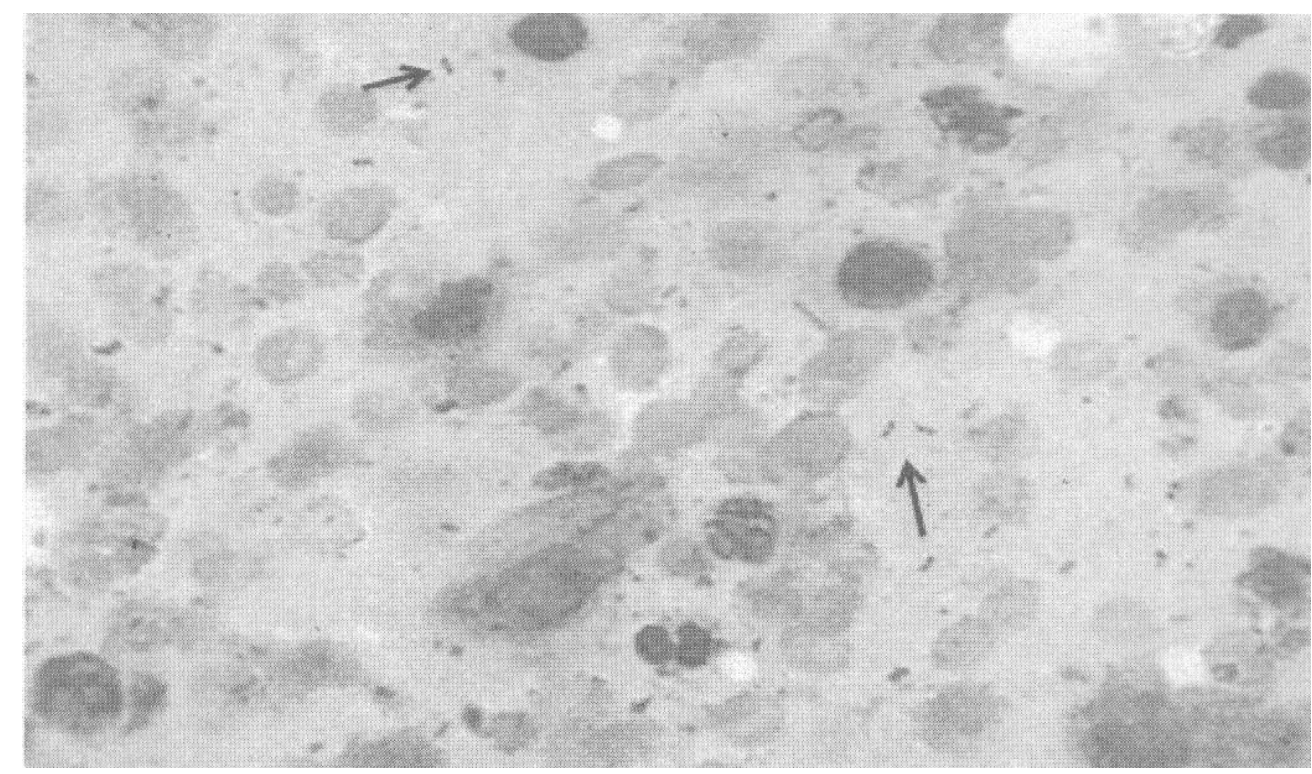

Photograph (3): Showing multocida in rat liver impression smear from a case of Septicaemia with the characteristic bipolar staining 
Gamal El-Din Ibrahim Mazyed et., al.

Incidence of Mannheimia multocida and Mannheimia haemolytica by ELISA:

Mannheimia multocida A3 and Mannheimia haemolyticaA1 are the only serotypes that recovered from the pneumonic calf samples.

Table (1): Incidence of Mannheimia multocida and Mannheimia haemolytica serotypes

\begin{tabular}{||l||c||c||c||}
\hline \multicolumn{1}{|c||}{ Paseurella spp } & Serotype & Number & \% \\
\hline \hline Mannheimia multocida & A3 & 47 & 37.9 \\
\hline Mannheimia haemolytica & A1 & 38 & 30.6 \\
\hline
\end{tabular}

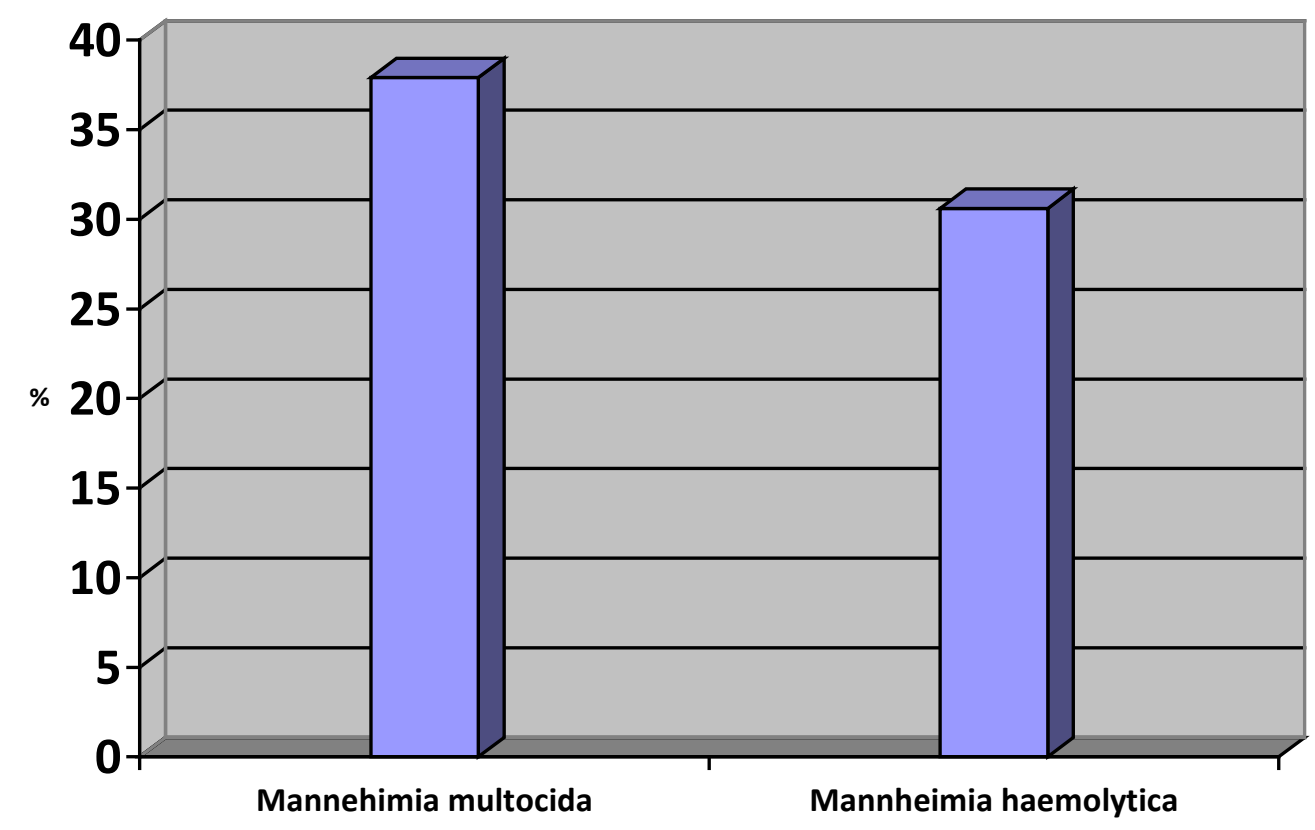

Fig. (1): Incidence of Mannheimia multocida and Mannheimia haemolytica $\overline{\overline{\text { Kafrelsheikh Vet. Med. J. Vol. } 15 \text { No. } 1 \text { (2017) }}}$ 


\section{DISCUSSION}

The genus Mannheimia is a member of the Paseurellaceae family, which includes a large and diverse group of Gram-negative Gammaproteobacteria, whose members are not only human or animal commensals and/or opportunistic pathogens but also outrightpathogens (Christensen and Bisgaard 2010).

In this study incidence of Mannheimia multocida isolates was $37.9 \%$ out of 124 non repeated bacterial isolates were recovered from 170 pneumonic calf samples, this result was nearly similar to Abd-El-Kaliek et al, (2013) (42.8\%) while other authors reported a lower incidence, 26.0\% by Pardon et al, (2011), 15.89\% by Sayed and Zaitoun (2009), 16.5\% by Hotchkiss et al, (2010), 20.7\% by Bell et al, (2014), 10\% by Khamesipour et al, (2014) and $26.5 \%$ by Enany et al, (2012), also higher incidence has been reported as $57.4 \%$ by Catry et al, (2006) and 61.54\% by Mohammadi et al, (2006). Incidence of Aannheimia mannheimia isolates was 30.6\% that nearly agree with 37.6\% by $\boldsymbol{A b d - E l -}$ Kaliek et al, (2013). Higher incidence was 73\% by Van Donkersgoed $\boldsymbol{e t}$ al, (1993), Lower incidence 3.2\% by Catry et al, (2006), 8\% by Kaoud et al (2010), 7.2\% by Enany et al, (2012) and 13\% by Saed et al., (2015).

The disease outcome is affected by various host and pathogen specific determinants. Several bacterial species-specific putative virulence factors including the capsular and virulence associated genes have been proposed to play a key role in this interaction. Virulence factors play an important role in disease production by bacterial pathogens. Among others, their functions include competence, adherence, synthesis, and export of capsules and evasion of host immune responses (Nanduri et al, 2009). In the current study super oxide. 


\section{REFERENCES}

- Abd El-Khalick, A.A., Selim, M.A. and Rizk, M.K. (2013). Bacterial isolates from calves slaughtered at Abattoir suffering from respiratory problems in Sharkia governorate. World Rural Observ., 5(1): 47-51.

- Bell, C J., Blackburn, P., Elliott M., Tony L A., Pattersan R, Eilison S., Lahuerta-Marin A. and Hywel J. B. (2014): Investigation of polymerase chain reaction assays to improve detection of bacterial involvement in bovine respiratory disease. Journal of Veterinary Diagnostic Investigation 1-4.

- Catry B, Decostere A, Schwarz S, Kehrenberg C, de Krulf A and Haesebrouck F (2006): Detection of tetracycline-resistant and susceptible Mannheimia ceae in the nasopharynx of loose grouphoused calves. Veterinary Research Commu-nications30: 707-715.

- Christensen, H., and Bisgaard M. (2010): Molecular classification and its impact on diagnostics and understanding the phylogeny and epidemiology of selected members of Mannheimia ceae of veterinary importance. Berl. Munch. Tierarztl. Wochenschr. 123:20 -30.

- Confer, W. A., (2009). Update on bacterial pathogenesis in BRD. Cambridge University Press Animal Health Research Reviews 10(2); 145-148 ISSN 1466-2523

- Duff, G.C.; Galyean, M.L. (2007). Recent advances in management of highly stressed newly received feedlot cattle. J. Anim. Sci., 85: 823-840. 
- Griffin, D., Chengappa, M.M., Kuszak, J. and McVey, D.S. (2010). Bacterial pathogens of the bovine respiratory disease complex. Vet. Clin North Am. Fodo Anim. Pract., 26: 381-394.

- Hotchkiss, E.J.; Dagleish, M.P., Willoughby, K., McKendrick, I.J., Finalyson, J., Zadoks, R.N., Newsome, E., Brulisauer, F., Gunn,G.J. (2010). Prevalence of Mannheimia multocida and other respiratory pathogens in the nasal tractof Scottish calves. Veterinary Record, 167: 555-560.

- Kaoud, H.; El-Dahshan, A.R.;Zaki, M.M.,Nasr,A.S. (2010). Occurrence of Mannheimia haemolyticaand Mannheimia trehalosi among ruminants in Egypt. New York Sci., J., 3(5):135-141.

- Khamesipour, F.; Momtaz, H. and Mamoreh, M. (2014). Occurrence of virulence factors and antimicrobial resistance in Mannheimia multocida strains isolated from slaughter cattle in Iran. Front. Microbiol., 5: 536-542.

- Mohammadi,G.R., Ghazvini, K.,Abbas Panah H. (2006). Antimicrobial susceptibility testing of Mannheimia haemolyticaand Mannheimia multocida isolated from calves.Archives of Razi Institute, 61(2): 91-96.

- Nanduri, B., Shack, L.A., Burgess, S.C. and Lawrence, M.L. (2009). The transpirational response of Mannheimia multocida to three classes of antibiotics. B.M.C. Genomics, 10-54.

- Pandher K, Confer,A.W. and Multphy, G.L. (1998). Genetic and immunologic analyses of PlpE, lipoprotein important in complement mediated killing of Pasteurella haemolytica serotype 1. Infect. Immun. 66:5613-5619. 
- Pardon, B, De Bleecker, K.,Dewulf J., Callens J., Boyen F., Catry B., Deprez P. (2011). Prevalence of respiratory pathogens in diseased non-vaccinated routinely medicated veal calves.Vet.Rec.169: 278.

- Saed, M., Khalid,S., Abd El-Mageed, A., Khalifa, E. (2015). Genome sequences of Gep Gene of Mannheimia haemolyticaserotype A1 and A2 associated with respiratory manifestation of ruminant in Egypt. Global Veterinaria, 14(1): 142-148.

- Sayed, M.S. and Zaitoun, M.A. (2009). Aerobic bacterial pathogens of Pneumonic feedlot buffalo-calves in Assiut Governorate. Egypt Ass. Univ.Bull. Environ. Res. Vol. 12, No. 1.

- Snowder, G.D., Van Vleck, L.D., Cundiff, L.V., Bennett, G.L. (2006). Bovine respiratory disease in feedlot cattle: environmental, genetic and economic factors. J. Anim. Sci., 84: 1999-2008.

- USDA 2013. Feedlot 2011 Part IV: Health and health management on U.S. feedlots -with a capacity of 1000 or more head.

- Van Donkersgoed, J., Ribble, C.S., Boyer, L.G. and Townsend G.G. (1993). Epidemilogical study of Enzootic pneumonia in dairy calves in Saskatchewan. Can. J. Vet. Res., 1993, 57: 247-254. 